\title{
Are Religious People More Caring? Exploring the Impact of Religiosity on Charitable Organizations in a Developing Country
}

\begin{abstract}
The purpose of this study is to explore the impact of religiosity on reasons that individuals volunteer. Additionally, this study will investigate the pro-social attitudes toward helping others and charitable organizations. This study focuses on Indonesia where religion plays an important role in daily life. The data was derived from a convenience sampling at a large private university in Surabaya, Indonesia $(\mathrm{N}=258)$. The results showed that individuals with high intrinsic and extrinsic personal religiosity were more likely to have 'other-oriented' reasons when performing philanthropic activities. Nonetheless, religiosity did not influence attitudes of individuals toward helping others. This study contributes to the debate regarding the effect of religious values on pro-social attitudes in the context of a developing country. Furthermore, the study provides social implications for researchers, policy makers, and practitioners operating in a developing country. This is one of the first few studies exploring the impact of religion on attitude toward charitable organization in Indonesia.
\end{abstract}

Keywords Charitable Organization, Developing Country, Religiosity, Volunteer, 


\section{Introduction}

Philanthropy is an integral part of almost all religion (Queen, 1996). Christianity teaches the parable of the 'Good Samaritan' (Luke 10: 25-37), while the Quran teaches generosity is a virtuous trait that every Muslim should strive to attain (Quran 2:272). Helping others is recognized as a universal trait taught by all major religions of the world (Chau et al., 1990). The impact of these teachings is that religion plays an important role in giving and volunteering to charities and non-profit organizations (Eckel and Grossman, 2004; O’Neill 1989). Two-thirds of the world's population has various religious affiliations, consequently, charity and religion becomes inseparable (Ranganathan and Henley, 2007).

Volunteerism, often defined as giving time and effort in an institution for the benefit of others and without any compensation, is an important pro-social behaviour that is often the backbone of various humanitarian efforts (Johnson, Cohen, and Okun, 2013; Pilavin and Siegl, 2007). Furthermore, religious institutions account for fully half of all volunteering and charitable contributions in the United States (Putnam, 2000; Smidt et al., 2008).

Studies report that religion or spirituality is one of the main reasons for helping others (Batson et al., 1999; Batson and Gray, 1981; Colby and Damon, 1992; Perry et al., 2008). Individuals are more likely to volunteer in both religious and secular settings if they belong to a religious group (Crystal and DeBell, 2002; Gibson, 2008). Nonetheless, studies on the relationship between religion and volunteering are inconsistent (Yeung, 2004). Some studies found no or limited correlation between religion and pro-social attitudes (Benson et al., 1980; Cnaan, Kasternakis, and Wineburg, 1993; Hunter and Linn, 1980; Wuthnow, 1991). Johnson, Cohen, and Okun (2013) found that intrinsic religiosity was not a significant predictor of secular volunteerism and this showed that religious teachings were not emphasizing assistance to out-of group members. In contrast, other studies found positive correlation between religion and volunteering (Clary and Snyder, 1991; Greeley, 1997; Lam, 2002; 
Uslaner, 1997; Omoto, Snyder, and Martino, 2000; Regnerus, Smith, and Sikkink, 1998; Wilson and Janowski, 1995).

Despite many indications of the active commitment of religious congregation and individuals to voluntary action (Hodgkinson, Weitzman, and Kirsch, 1988; Cnaan et al. 1993), most of the previous studies are conducted mainly in the developed countries. There has been little research on the perception and attitude of individuals toward religious and nonreligious institutions in the context of a developing country, where religion plays an important role in daily life. For example, percentages of people who claim not to have any religious affiliation are only 3.4\% percent in Indonesia and $0.1 \%$ percent in India (CIA Word Factbook, 2013). Furthermore, the world's poorest nations have the highest proportion of religious people and 98\% of them say that religion is important in daily live (Crabtree, 2010). Thus, the purpose of this study is to explore the impact of religiosity on reasons why individuals volunteer and on the pro-social attitudes toward helping others and charitable organizations in Indonesia. This study contributes to the debate regarding the effect of religiosity on pro-social attitudes in a developing country. Ranganathan and Henley (2008) suggest that the ability to measure attitudes toward charitable organization is important for researchers, policy makers, and practitioners alike.

\section{Background}

The conceptual framework of this study is based on Behavioural Reasoning Theory (BRT) (Westaby 2005). BRT explains functional motives or reasons for individual behaviours that serve as a linkage between values, beliefs, attitudes, intentions, and behaviour (Briggs, Peterson, and Gregory, 2010). The higher the priority of a value, the more likely it will affect an individual's reasoning associated with a particular behaviour (Briggs, Peterson, and Gregory, 2010). The theory suggests that reasons influence global motives and intentions 
because they help individuals rationalize and defend their action, which often promotes and protect their self-worth (Westaby, 2005). Thus, individuals' religious values, which often become their self-worth, will subsequently influence their attitude and behaviour toward charitable organizations. The more religious they are the, the more likely they want to express their values in order to be considered successful or highly regarded in their religious community. The conceptual framework on Figure 1 illustrates the predicted relationship between individual religious values and the reason for volunteering and pro-social attitudes (i.e. attitude toward helping others and attitude toward charitable organizations). The next section discusses the rationale behind the connections in the conceptual framework and presents the study hypotheses.

\section{Insert Figure 1 About Here}

\section{Literature Review and Hypothesis Development}

To acquire further insights into the role of religiosity on the attitude of an individual toward charitable organization, the literature review section offers definitions and previous research findings on these issues. This section begins by outlining the extant literature on religiosity (intrinsic and extrinsic), reason for volunteering, and pro-social attitude (i.e., attitude toward helping others and attitude toward charitable organization). Subsequently, several hypotheses are proposed.

\section{Religiosity}

Allport and Ross (1967) defined religiosity as the extent to which a person lives out his or her religious beliefs. Similarly, McDaniel and Burnett (1990) defined religiosity as a belief in God followed by a commitment to follow rules and principles believed to be set by God. Religious motivations can be viewed in terms of intrinsic and extrinsic religiosity that can 
differentiate religious motivation (Allport and Ross, 1967; Arli and Tjiptono, 2014; Vitell, Sing and Paollilo, 2007; Vitell, 2010). The nature of intrinsic and extrinsic religiosity has been some of the most discussed topics in the psychology of religion in the last 50 years (Allport and Ross, 1967). The intrinsically motivated person lives his religion while the extrinsically motivated one uses his religion (Allport and Ross, 1967; Vitell, Sing and Paollilo, 2007). Therefore, there are different dimensions of religiousness. Intrinsic religiosity is the highest form of cognitive dimension. Someone with high intrinsic religiousness will consider the benefits of religion (e.g., meeting friends etc.) less important compared to his/her relationship with God. An individual with strong intrinsic religiousness tends to live daily life according to her/his religion (Vitell et al., 2005). In contrast, extrinsic religiosity is a behavioral dimension of religiousness. An individual with strong intrinsic religiousness tends to live daily life according to her/his religion. In contrast, an individual with strong extrinsic religiosity might be more influenced by social determinants and participate in religious activities to meet personal needs (e.g., source of comfort and peace) or for social goals (e.g., social support). These people use religion to achieve instrumental goals (Johnson et al. 2013).

Intrinsic motivation to volunteer may come through the internalization of certain norms or values such as religion (Hill and Dulk, 2013; Vitell and Paolillo, 2003). Personal religiosity has been shown to explain the nature of an individual’s ethical behaviour (Magill 1992). In the context of Christianity, studies show that religiosity should encompass an individual's religious beliefs, frequency of worship, and perceived importance of spiritual values (Wilkess et al., 1986; Ranganathan and Henley, 2007). Individuals who attend church were twice as likely to volunteer and give compared to those who did not attend church (Jackson et al., 1995; Wilson and Janoski, 1995). Specifically, studies that separate between intrinsic and extrinsic religiosity found a distinction between the two. Individuals with high 
intrinsic religiosity are more ethical when faced with various ethical consumer situations (Arli and Tjiptono, 2013; Vitel and Paolilo, 2003), are more likely to help others without remuneration (Graham, 1990; Wuthnow, 1991), volunteer and give (Hoge and Yang, 1994; Jackson et al., 1995), and correlate with altruism (Smith et al., 1999). Based on the previous analysis, it is reasonable to predict that individuals with high intrinsic religiousness would place a higher degree of importance on religion thus making these individuals more likely to have a positive attitude as part of expressing his/her value and less likely to ask for something in return. Thus, we propose the following hypotheses:

$\mathbf{H}_{1}$ : Individual intrinsic religiosity is significantly related to: (a) the importance individuals assign to value expression (+); (b) attitude toward helping others (+) and; (c) the importance individuals assign to career benefits (-).

Nonetheless, Donahue (1985) suggests that extrinsic religiosity is correlated with less religious commitment. This individual can be very active in a congregation and not religious. In that case, these individuals will be motivated by external social pressures to use religion to achieve goals (Cnaan, Kasternakis, and Wineburg, 1993). This religious value is strictly utilitarian. Arli and Tjiptono (2013) found that individuals with high extrinsic religiosity are less ethical than individuals with high intrinsic religiosity. It can be concluded that individuals with a high degree of extrinsic religiosity are not as committed to their religion as they might appear to be, thus might have less positive attitude and seek external benefits from involvement in a religious institution. Thus, we hypothesize the following:

$\mathbf{H}_{2}$ : Individual extrinsic personal religiosity is significantly related to: (a) the importance individuals assign to value expression (-); (b) attitude toward helping others (-) and; (c) the importance individuals assign to career benefits $(+)$.

$\mathbf{H}_{3}$ : Individual extrinsic social religiosity is significantly related to: (a) the importance individuals assign to value expression (-); (b) attitude toward helping others (-) and; (c) the importance individuals assign to career benefits $(+)$. 
Reason for Volunteering

Volunteering can be defined as any activity in which time is given freely to benefit other individuals or organizations (Wilson, 2000). This definition may not exclude volunteers from benefiting from their charity (Wilson, 2000). Clary et al. (1998) designed the Volunteer Functions Inventory (VIF) for capturing six motivational reasons (i.e., values, career, understanding, social, protective, and enhancement) by volunteerism. Of these motivational reasons, values and career enhancement have been found to be more predictive of volunteering behaviour than the others (Houle et al. 2005; Briggs et al., 2010; Mowen and Sujan, 2005). Value function such as self-sacrifice and altruism for others are often served by volunteerism (Carmen, 1992; Verplanken and Holland, 2002). The conceptual definition is "the individual volunteers in order to express or act on important values like humanitarianism” (Clary and Snyder, 1999, p. 157). This reason can be considered as ‘otheroriented’ (Briggs et al., 2010). In contrast, career function serves as career-related benefits and skills that one might acquire by engaging in volunteerism. Career function can be defined as "the volunteer has the goal of gaining career-related experience through volunteering" (Clary and Snyder, 1999, p. 157). This reason can be classified as “me-oriented” (Briggs et al., 2010; Clary et al., 1998). Based on the previous logic, we hypothesize the following $\mathbf{H}_{4}$ : The importance individuals assign to value expression is significantly related to their attitude toward charitable organizations $(+)$.

$\mathbf{H}_{5}$ : The importance individuals assign career benefits is significantly related to their attitude toward charitable organizations (-).

Pro-Social Attitudes (Attitudes Toward Helping Others and Attitude Toward Charitable Organization).

Behavioral Reasoning Theory (BRT) suggests that reasons will serve as antecedents of attitudes. Individuals will form favourable attitudes toward behaviour where they have strong reasons to support that activity (such as volunteering). Webb, Green, and Brashear defined 
attitude toward helping others (AHO) as "global and relatively enduring evaluation with regard to helping or assisting other people” (2000, p. 300). While attitude toward charitable organization (ATCO) can be defined as "global and relatively enduring evaluations with regard to the non-profit organizations that help individuals” (Webb, Green, and Brashear, 2000, p. 300). AHO is considered as an attitude toward behaviour while ATCO is an attitude toward a target that specifies the objects of a particular action (Eagly and Chaiken, 1993). AHO is more general in nature while ATCO is more specific (Ranganathan and Henley, 2008). Studies show that how people feel about helping others is influenced by personal norms (Webb, Green, and Brashear, 2000; Pilliavin and Chang, 1990) and individuals attitude are related positively to donation behaviour (Burnkarant and Page, 1982; LaTour and Manrai, 1989; McIntyre et al., 1986). Webb, Green, and Brashear (2000) concluded that an individual with positive AHO who donated to a charitable organization found this as a good part way to attain the goal of helping others. Furthermore, unlike spontaneous help given to the victim of an accident or assaults, volunteerism typically is proactive rather than reactive and may require commitment of time and effort (Wilson, 2000).

Consequently, based on Webb, Green, and Brashear’s (2000) arguments, attitude toward helping others will be related toward one's attitude of a charitable organization. Thus, we will test the following hypotheses:

$\mathbf{H}_{6}$ : Individuals attitude toward helping others is significantly related to their attitude toward charitable organizations $(+)$.

\section{Methodology}

Research Context and Sample Research

Indonesia is the fourth most populous nation in the world with around 240 million people and the largest country in Southeast Asia (Population Reference Bureau, 2011). Indonesia is a country of cultural diversity and home to the largest Muslim population in the world with 
86.1\% of the population, followed by $8.7 \%$ Christian/Catholic, $1.8 \%$ Hindu, and 3.4\% other or unspecified. Despite high percentages of Muslims, Indonesia is not an Islamic state. Indonesia legally recognises five religions namely Islam, Christianity, Catholicism, Hinduism, and Buddhism. Consequently, each citizen needs to declare a religion on his/her identity card. Religion is an important part of Indonesia and influences political, cultural, and economic life (Seo, 2013). Moreover, despite its large population and poor economic condition, a study found that a large proportion regularly gives either monetary or in-kind help (Saidi, 2002).

The data was derived from a convenience sampling at a large private university in Surabaya, Indonesia. Lecturers hand-delivered approximately 300 questionnaires to undergraduate students in classrooms at the university. However, only 258 questionnaires were usable, thereby offering an overall response rate of $86 \%$. In the sample, $27.5 \%$ are male and $72.5 \%$ are female. Most were single (95.7\%). The majority was Muslim (66.3\%), followed by Christians (17.8\%), Catholics (9.7\%), Buddhist (3.1\%), Hindu (1.6\%), and others (3.1\%). Table 1 summarises the demographic profile of respondents.

\section{Insert Table 1 About Here}

\section{Measure}

Measure of all latent variables was captured using previously validated scales. Religiosity was measured using Allport and Ross's (1967) scale that measures intrinsic and extrinsic social attitudes and extrinsic personal dimensions. The revised intrinsic/extrinsic religiousness scales adapted from Allport and Ross (1967) by Kirkpatrick (1988) measured religiousness. Allport's Religious Orientation Scale (ROS) is one of the most frequently used measures to determine the degree to which a person internalises and practices religious beliefs and values (Donahue, 1985; Vitell et al., 2009). As previously discussed, extrinsic religiousness divided into these two categories, 'Es' for socially oriented extrinsic items and 
‘Ep’ for personally oriented extrinsic items. Intrinsic religiosity (e.g. I try hard to live all my life according to my religious beliefs), extrinsic personal religiosity (e.g. Prayer is for peace and happiness), and extrinsic social religiosity (e.g. I go to religious services mostly to spend time with my friends) all must be measured.

Measures of reason for volunteering (i.e. value expression and career reasons) were based on the Volunteer Functions Inventory from Clary et al. (1998). Examples of items from value expression (e.g., I feel compassion toward people in need) and career (e.g. Volunteering allows me to explore different career options) are important to understand. Subjects were asked to indicate how important or accurate each of the reasons for volunteering was to him/her, using a response scale ranging from 1 (not at all important/accurate) to 5 (extremely important/accurate).

Furthermore, five items were used to capture each of the reasons for volunteering. Finally, measures of pro-social attitude, AHO (e.g. People should be willing to help others who are less fortunate) and ATCO (e.g. Charitable organizations have been quite successful in helping the needy) were based on the work of Webb, Green, and Brashear (2000) using a response scale ranging from 1 (strongly disagree) to 5 (strongly agree). Table 2 summarises the scale items used in this study.

Structural equation modelling using AMOS 21 analysed the data. The two-step procedure of Gerbing and Anderson (1988) was followed, whereby a single confirmatory factor analysis (CFA) was estimated including all constructs before estimating the structural model. Scale items with low loading scores below the .5 criterion were removed from the analysis (Bagozzi and Yi, 1988). The comparative fit index (CFI), Tucker-Lewis Index (TLI), and Incremental Fit Index (IFI) were all above .91. Furthermore, the root mean square error of approximation (RMSEA) was less than .06. The cronbach alpha for all scales was above the .7 criterion (Nunnaly, 1978) and the average variance extracted (AVE) of all samples was 
at or above the .5 criterion suggested by Fornell and Larcker (1981). Table 3 shows the means value and standard deviation of each construct. Table 4 shows the correlations included in the model. Finally, Table 5 shows the scales factor loadings, construct reliabilities, variance extracted, and composite reliabilities.

\section{Insert Table 2-5 About Here.}

A structural model derived from the conceptual model in figure 1 was then estimated (Hair et al., 1998). Figure 2 shows the results of the hypothesized paths and significant paths. Table 6 reports estimates for all paths modelled in the study. The fit of the structural model was good, with $\mathrm{X}^{2}{ }_{(283)}=453.914, \mathrm{CFI}=.945, \mathrm{TLI}=.937, \mathrm{IFI}=.946, \mathrm{RMSEA}=.048$. The following sections discuss the result further.

Insert Figure 2 and Table 6 About Here

\section{Results}

Intrinsic Religiosity

The results provided support Hypothesis 1a. Intrinsic religiosity of an individual is positively related to value expression $(\beta=.491, p<.001)$. Nonetheless, we found no support for Hypothesis 1b. Intrinsic religiosity of an individual was not positively related to attitude toward helping others. It shows that religious people may prefer to help others but only within their religious group. Similarly, no support was found for Hypothesis 1c. Intrinsic religiosity of an individual was not negatively related to career benefits. Intrinsic religiosity did not negatively influence people's reason to volunteer as part of their career prospects. Religious people in Indonesia may see volunteering as part of their opportunity to widen their networks for future career prospect. 


\section{Extrinsic Religiosity}

Support was not found for hypothesis 2a due to the opposite direction of the result. The extrinsic personal religiosity of an individual is positively related to the importance that individuals assign to value expression $(\beta=.298, p<.05)$. Furthermore, hypothesis $2 \mathrm{~b}$ was not supported. The standardized value was negative but not significant. Individuals' extrinsic personal religiosity was not negatively related to attitudes toward helping others. Similarly, no support was found for hypothesis 2c. The standardized value was positive but not significant. Individuals’ extrinsic personal religiosity was not positively related to the importance individuals assign to career benefits.

Moreover, support was found for hypothesis 3a. Individuals’ extrinsic social religiosity was negatively related to the importance individuals assign to value expression $(\beta=-.147, p<.05)$. No support was found for hypothesis 3b and 3c. Individuals' extrinsic social religiosity was not significantly related to attitude toward helping others and the importance individuals assign to career benefits. In regards to career prospect, the overall results show that religiosity has no effect on their reason for volunteering. The results show positive effect but not significant. This shows that religious people, irrelevance of their level of religiosity may use volunteering as an opportunity to build network and advance their career, especially for the younger generation.

Reason for Volunteering and Pro-Social Attitude

Support was found for hypothesis 4. The importance individuals assign to value expression was positively related to their attitude toward charitable organizations $(\beta=.551, p<.01)$. Nonetheless, no support was found for hypothesis 5 . The importance individuals assign to career benefits was not related negatively to their attitude toward charitable organizations. 
Finally, this study found support for hypothesis 6. Individual attitudes toward helping others is related positively towards charitable organizations $(\beta=.732, p<.01)$.

\section{Discussion}

Our purpose in this study is to explore the impact of religiosity on reasons that individuals volunteer and on the pro-social attitudes toward helping others and charitable organizations. In the context of a developing country, this study revealed that religiosity affects the reasons that individuals volunteer. Individuals with high intrinsic religiosity tend to focus more on others. A surprise finding is that individuals with high extrinsic personal religiosity tend to have "other-oriented focus” as well. It shows that getting personal benefits from religion, such as peace, happiness, and comfort did not change ones perspective towards benefiting others. Furthermore, individuals with high extrinsic social religiosity are less likely to focus on others. Consequently, studies on extrinsic religiosity should separate between extrinsic personal and social religiosity because individuals with high extrinsic personal religiosity may exhibit similar attitude with individuals that have high intrinsic religiosity.

Moreover, intrinsic and extrinsic religiosity did not influence attitudes toward helping others. This finding is in contrast with Ranganathan and Henley (2008) that found religiosity is an important antecedent variable in predicting favourable attitude toward helping others. However, Ranganathan and Henley’s (2008) study did not separate between intrinsic and extrinsic religiosity. Thus, studies on religiosity should separate between the two. People who are coming to a religious institution might not be as religious as they appear. Studies have shown that church attendance was not always related to volunteering, helping others, and giving (Amato, 1985; Latane and Darley, 1970). Our findings support Wuthnow’s conclusion that suggested "participation in religious organization, it appears, has a genuine, but limited, effect on charitable behaviour" and that "the kinds of activities that are 
encouraged seem to be ones closely connected with the church itself” (1991, p. 26). It shows that the relationship between religiosity and helping others may not be strictly linear (Einolf, 2011) and participation in religious groups may create a relatively closed social network (Smith, 2003; Johnson et al. 2013). Individuals with high intrinsic religiosity may not extend their compassion to member of out-groups (Batson et al., 1999). Similarly, Cnaan, Kasternakis, and Wineburg (1993) found no significant relationship between religious belief and volunteering unless the volunteer works took place within a religious congregation.

It appears that religious people, in the context of developing countries, may act similarly to believers in the developed countries. They first focus on helping within their own congregation then eventually assist others when they are in surplus. This finding may have implications for religious leaders to encourage members to donate and volunteer beyond their own religious walls in order to make more contributions to their community. Religious leaders may not realize the consequences of their teachings where members of their congregations tend to focus on their own group.

Moreover, this study shows that value expression or "other-oriented” reasons contribute to higher levels of AHO and significantly influenced attitudes toward charitable organizations. Our research findings are consistent with studies conducted in the developed countries (Briggs et al., 2010; Mowen and Sujan, 2005; Penner and Finkelstein, 1998), where the importance that individuals assign to value expression was positively related to people’s attitude toward helping others. Furthermore, career benefits or "me-oriented" thoughts did not influence attitudes toward helping others. The results are also consistent with other studies (i.e. Briggs et al.’s, 2010; Carman, 1992). In the context of developed countries, career did not influence people's attitude toward helping others. Extrinsic reward may be in direct conflict with intrinsic motivation to help other. Therefore, government or not-for-profits operating in the developing countries should tap into this reasoning, reminding 
volunteers that philanthropy activities are about helping others more unfortunate than themselves and not about career advancement or getting skills. In the context of Indonesia, promoting volunteering work as a way to help people develops skills, expands networks, gain career-related experience may not be as effective as promoting volunteer as an altruism act that benefits others. Similar to studies in the developed countries (Briggs et al., 2010; Mowen and Sujan, 2005; Penner and Finkelstein, 1998), identifying and activating core values in promoting a cause is an important element of an effective volunteers 'recruitment campaign. Campaign ads that can increase value-congruent behaviour are more likely to increase positive perception of the organisation and increase volunteers' willingness to join the cause (Briggs et al., 2010; Verplanken and Holland, 2002). The study confirms that people's attitude toward helping other and charitable organisation are very similar in both developed and developing countries.

\section{Limitation and Future Research}

Limitations are inevitable in any convenience sampling. Similar to other ethical studies that used student populations (e.g., Burnet et al., 2003; Nevins et al., 2007); our samples came from student populations in one city in Indonesia. Future research should obtain data from other demographic categories (i.e., age, income, and ethnic) in other cities in Indonesia, because this may produce more generalizable results. Therefore, expanding the sample demographics is necessary. Moreover, due to a small sample size for each religion, this study did not explore differences between religions. Future studies may examine and compare the impact of a specific religion (e.g, Muslim, Christian, Catholic etc) toward charitable organizations. In addition, these students may or may not involve in a particular volunteer activity. The survey contains hypothetical questions exploring students' future volunteering 
activity $^{1}$. Furthermore, how volunteers are recruited in Indonesia is relatively understudied. This offers future research opportunity for investigating how not-for-profit organisations in Indonesia recruit and maintain their volunteers (e.g. word-of-mouth, referrals, advertising, social media, etc.). This research will help increase the effectiveness of volunteers recruitment in Indonesia. ${ }^{2}$

Despite the mentioned limitations, these results revealed intrinsic religiosity as an important influence on the reason for volunteering. An individual's religiousness cannot be dismissed in volunteering and pro-social behaviour research, especially in the context of developing countries.

\footnotetext{
${ }^{1}$ We thank an anonymous reviewer for this feedback

${ }^{2}$ We thank an anonymous reviewer for this feedback
} 


\section{References}

Allport, G. W. and Ross, J. M. 1967. Personal religious orientation and prejudice. Journal of Personality and Social Psychology, 5: 447-457.

Amato, P. R. 1985. An investigation of planned helping behaviour. Journal of Research in Personality, 19(2): 232-252.

Arli, D., and Tjiptono, F. (2014).The End of Religion? Examining the Role of Religiousness, Materialism, and Long-Term Orientation on Consumer Ethics in Indonesia. Journal of Business Ethics, 123(4): 385-400.

Bagozzi, R.P. and Yi, Y. (1988).On the evaluation of structural equation models. Journal of the Academy of Marketing Science, 16: 74-94.

Batson, C. D., and Gray, R. A. (1981). Religious orientation and helping behavior: Responding to one's own or the victim's needs?. Journal of Personality and Social Psychology, 40(3): 511.

Batson, C. D., Ventis, W. L., and Batson, D. C. (1982). The religious experience: A socialpsychological perspective (pp. 28-9). New York: Oxford University Press.

Batson, C. D., Floyd, R. B., Meyer, J. M., and Winner, A. L. (1999). And Who Is My Neighbor?:" Intrinsic Religion as a Source of Universal Compassion. Journal for the Scientific Study of Religion, 445-457.

Benson, P. L., Dehority, J., Garman, L., Hanson, E., Hochschwender, M., and Lebold, C. S. C. (1980).Intrapersonal correlates of non-spontaneous helping behaviour. Journal of Social Psychology, 110: 87-95.

Briggs, E., Peterson, M., and Gregory, G. (2010).Toward a better understanding of volunteering for nonprofit organizations: explaining volunteers' pro-social attitudes. Journal of Macromarketing, 30(1): 61-76.

Burnkrant, R. E., and Page Jr, T. J. (1982).An examination of the convergent, discriminant, and predictive validity of Fishbein's behavioral intention model. Journal of Marketing Research, 550-561.

Burnett, M., Keith, N. and Pettijohn, C. (2003).An empirical analysis of factors influencing student reactions to ethical advertising dilemmas: Educational experience, work experience, ethical philosophy, and demographics. Marketing Education Review, 13: 33-46

Carmen, J.M. (1992). Theories of altruism and behaviour modification campaigns. Journal of Macromarketing, 12:5-18.

Chau, L. L., Johnson, R. C., Bowers, J. K., Darvill, T. J., and Danko, G. P. (1990).Intrinsic and extrinsic religiosity as related to conscience, adjustment, and altruism. Personality and Individual Differences, 11(4): 397-400. 
Central Intelligence Agency. (2013), Indonesia, India. In The world factbook. Retrieved from https://www.cia.gov/library/publications/the-world-factbook/geos/sf.html.

Clary, E. G., Snyder, M., Ridge, R. D., Copeland, J., Stukas, A. A., Haugen, J., and Miene, P. (1998).Understanding and assessing the motivations of volunteers: a functional approach. Journal of personality and social psychology, 74(6): 1516.

Cnaan, R. A., Kasternakis, A., and Wineburg, R. J. (1993).Religious people, religious congregations, and volunteerism in human services: Is there a link?. Nonprofit and Voluntary Sector Quarterly, 22(1): 33-51.

Colby, A., and Damon, W. (2010), Some do care. Simon and Schuster

Crabtree, S. (2010).Religiosity highest in World's Poorest Nations. United States is among the rick countries that buck the trend. (accessed February 4, 2013) [available at http://www.gallup.com/poll/142727/religiosity-highest-world-poorest-nations.aspx]

Crystal, D. S., and DeBell, M. (2002).Sources of Civic Orientation Among American Youth: Trust, Religiious Valuation, and Attributions of Responsibility. Political Psychology, 23(1): 113-132.

Donahue, M .J. (1985).Intrinsic and extrinsic religiousness: Review and meta analysis. Journal of Personality and Social Psychology, 48(2): 400-419.

Eagly, A.H. and Chaiken, S. (1993), The psychology of attitudes. Orlando, FL.: Harcourt Brace Jovanovich.

Eckel, C. C., and Grossman, P. J. (2004).Giving to secular causes by the religious and nonreligious: An experimental test of the responsiveness of giving to subsidies. Nonprofit and Voluntary Sector Quarterly, 33(2): 271-289.

Einolf, C. J. (2011).Gender differences in the correlates of volunteering and charitable giving. Nonprofit and Voluntary Sector Quarterly, 40(6): 1092-1112.

Fornell, C., and Larcker, D. F. (1981).Structural equation models with unobservable variables and measurement error: Algebra and statistics. Journal of Marketing Research, 382-388.

Gerbing, D. W., and Anderson, J. C. (1988).An updated paradigm for scale development incorporating unidimensionality and its assessment. Journal of Marketing research, 186-192.

Gibson, Troy. (2008).Religion and Civic Engagement among America's Youth. The Social Science Journal, 45: 504-514.

Graham, G. (1990), The idea of Christian charity. South Bend, IN: University of Notre Dame Press.

Greeley, A. (1997), The other civic America: Religion and social capital. American Prospect, 68-73. 
Hill, J.P. and Dulk, D.K.R. (2013).Religion, volunteering, and educational setting: the effect of youth schooling type on civic engagement. Journal for the Scientific Study of Religion, 52(1): 179-197.

Hodgkinson, V.A., Weizman, M. and Kirsh, A. (1988), From belief to commitment: the activities of religious congregations in the United States. Findings from a national survey. Washington, DC: Independent Sector.

Hoge, R., and Yang, F. (1994). Determinants of religious giving in American denominations: Data from two nationwide surveys. Review of Religious Research, 123-148.

Houle, B. J., Sagarin, B. J., and Kaplan, M. F. (2005).A functional approach to volunteerism: Do volunteer motives predict task preference?. Basic and applied social psychology, 27(4): 337-344.

Hunter, K. I., and Linn, M. W. (1980).Psychosocial differences between elderly volunteers and non-volunteers. The International Journal of Aging and Human Development, 12(3), 205-213.

Jackson, E. F., Bachmeier, M. D., Wood, J. R., and Craft, E. A. (1995).Volunteering and charitable giving: Do religious and associational ties promote helping behavior?. Nonprofit and Voluntary Sector Quarterly, 24(1): 59-78.

Johnson, K.A., Cohen, A. and Okun, M.A. (2013). Intrinsic religiosity and volunteering during emerging adulthood: a comparison of Mormons with catholics and non-catholic Christian. Journal of the Scientific Study of Religion, 52(4): 842-851.

Lam, P. Y. (2002).As the flocks gather: How religion affects voluntary association participation. Journal for the Scientific Study of Religion, 41(3): 405-422.

Latane, B., and Darley, J. M. (1970), The unresponsive bystander: Why doesn't he help?. New York: Appleton-Century Crofts.

LaTour, S. A., and Manrai, A. K. (1989).Interactive impact of informational and normative influence on donations. Journal of Marketing Research, 327-335.

Kirkpatrick, L. A. (1989).A psychometric analysis of the Allport-Ross and Feagin measures of intrinsic-extrinsic religious orientation. Research in the social scientific study of religion, 1: 1-31.

Magill, (1992).Theology in business ethics: appealing to the religiousness imagination. Journal of Business Ethics, 11, 129-135.

McIntyre, P., Barnett, M. A., Harris, R. J., Shanteau, J., Skowronski, J., and Klassen, M. (1987).Psychological factors influencing decisions to donate organs. Advances in consumer research, 14: 331-334.

Nevins, J. L., Bearden, W. O. and Money, B. (2007).Ethical values and long-term orientation. Journal of Business Ethics, 71: 261-274 
Nunally, J.C. (1978). Psychometric theory. $2^{\text {nd }}$ ed. New York, NY: McGraw-Hills, Inc.

McDaniel, S. W. and Burnett, J. J. (1990).Consumer religiousness and retail store evaluative criteria. Journal of the Academy of Marketing Science, 18(2): 101-112.

Mowen, J. C., \& Sujan, H. (2005). Volunteer behavior: A hierarchical model approach for investigating its trait and functional motive antecedents. Journal of Consumer Psychology, 15(2), 170-182.

Omoto, A. M., Snyder, M., and Martino, S. C. (2000).Volunteerism and the life course: Investigating age-related agendas for action. Basic and applied social psychology, 22(3): 181-197.

O'Neill, M. (1989), The third America: The emergence of the nonprofit sector in the United States. San Francisco: Jossey-Bass.

Penner, L.A., Finkelstein, M.A., (1998). Dispositional and structural determinants of volunteerism. Journal of Personality and Social Psychology 11: 45-69.

Perry, J. L., Brudney, J. L., Coursey, D., and Littlepage, L. (2008).What drives morally committed citizens? A study of the antecedents of public service motivation. Public administration review, 68(3): 445-458.

Piliavin, J. A., and Charng, H. W. (1990).Altruism: A review of recent theory and research. Annual review of sociology, 27-65.

Piliavin, J. A., and Siegl, E. (2007).Health benefits of volunteering in the Wisconsin Longitudinal Study. Journal of Health and Social Behavior, 48(4): 450-464.

Putnam, R. D. (2001), Bowling alone: The collapse and revival of American community. Simon and Schuster.

Queen, E. L. (1996).The religious roots of philanthropy in the West: Judaism, Christianity. and Islam. (Working Paper Series,\# 96-4). Indianapolis: Indiana University Center on Philanthropy.

Ranganathan, S. K., and Henley, W. H. (2008).Determinants of charitable donation intentions: a structural equation model. International Journal of Nonprofit and Voluntary Sector Marketing, 13(1): 1-11.

Regnerus, M. D., Smith, C., and Sikkink, D. (1998).Who gives to the poor? The influence of religious tradition and political location on the personal generosity of Americans toward the poor. Journal for the Scientific Study of Religion, 481-493.

Saidi, Z. (2002), Developing self-reliance in giving: potential and pattern of giving and raising in Indonesia. Jakarta: Piramedia

Seo, M. (2013), State management of religion in Indonesia (Vol. 1). Routledge. 
Smidt, C. (1999).Religion and civic engagement: A comparative analysis. The Annals of the American Academy of Political and Social Science, 565(1): 176-192.

Smith, H. L., Fabricatore, A., and Peyrot, M. (1999).Religiosity and altruism among African American males: The Catholic experience. Journal of Black Studies, 29(4): 579-597.

Uslaner, E. M. (1995), Faith, hope, and charity: Social capital, trust, and collective action. In annual meeting of the American Political Science Association, Chicago.

Van Slyke, D. M., and Brooks, A. C. (2005).Why do people give? New evidence and strategies for nonprofit managers. The American Review of Public Administration, 35(3): 199-222.

Verplanken, B., and Holland, R. W. (2002). Motivated decision making: effects of activation and self-centrality of values on choices and behavior. Journal of personality and social psychology, 82(3), 434.

Vitell, S. J. and Muncy, J. (2005).The Muncy-Vitell consumer ethics scale: A modification and application. Journal of Business Ethics, 62: 267-275.

Vitell, S. J., and Paolillo, J. G. (2003).Consumer ethics: The role of religiosity. Journal of Business Ethics, 46(2): 151-162.

Vitell, S. J., Singh, J. J. and Paolillo, J. (2007). Consumers' ethical beliefs: The roles of money, religiousness and attitude toward business. Journal of Business Ethics, 73: 369-279.

Vitell, S.J. (2010). The role of religiousness in business and consumer ethics: a review of literature. Journal of Business Ethics 90: 155-167

Webb, D. J., Green, C. L., and Brashear, T. G. (2000).Development and validation of scales to measure attitudes influencing monetary donations to charitable organizations. Journal of the Academy of Marketing Science, 28(2): 299-309.

Westaby, J. D. (2005).Behavioral reasoning theory: Identifying new linkages underlying intentions and behaviour. Organizational Behavior and Human Decision Processes, 98(2): 97-120.

Wilkes, R. E., Burnett, J. J., and Howell, R. D. (1986).On the meaning and measurement of religiosity in consumer research. Journal of the Academy of Marketing Science, 14(1): 47-56.

Wilson, J., and Janoski, T. (1995).The contribution of religion to volunteer work. Sociology of religion, 56(2): 137-152.

Wilson, J. (2000).Volunteering. Annual review of sociology, 215-240.

Wuthnow, R. (1991), Acts of compassion: Caring for others and helping ourselves.

Princeton, NJ: Princeton University Press 
Yeung, A. B. (2004).An intricate triangle-religiosity, volunteering, and social capital: The European perspective, the case of Finland. Nonprofit and Voluntary Sector Quarterly, 33(3): 401-422. 


\section{Appendix}

Figure 1. Conceptual Framework

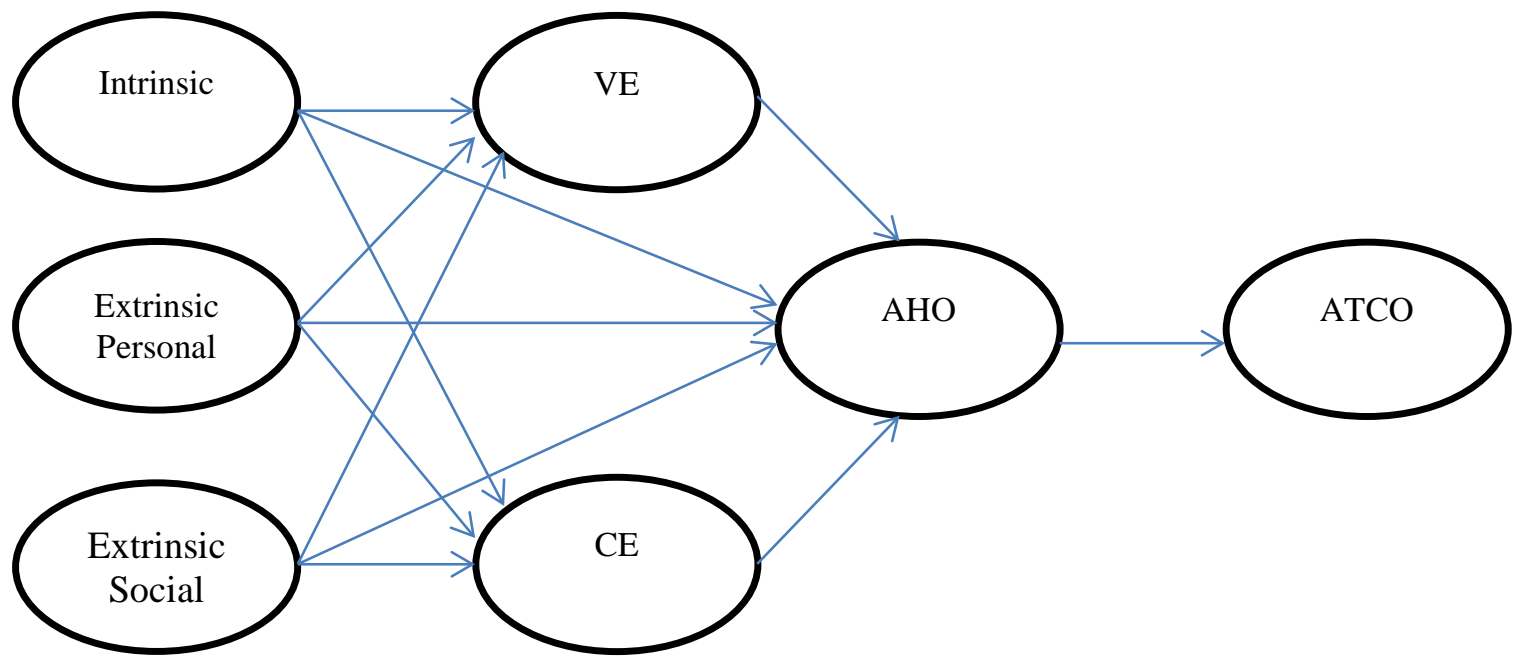

Note: $\mathrm{VE}=$ Value Expression; $\mathrm{CE}=$ Career; $\mathrm{AHO}=$ Attitude Toward Helping Others; ATCO = Attitude Toward Charitable Organization

Figure 2. Significant paths in Structural Model

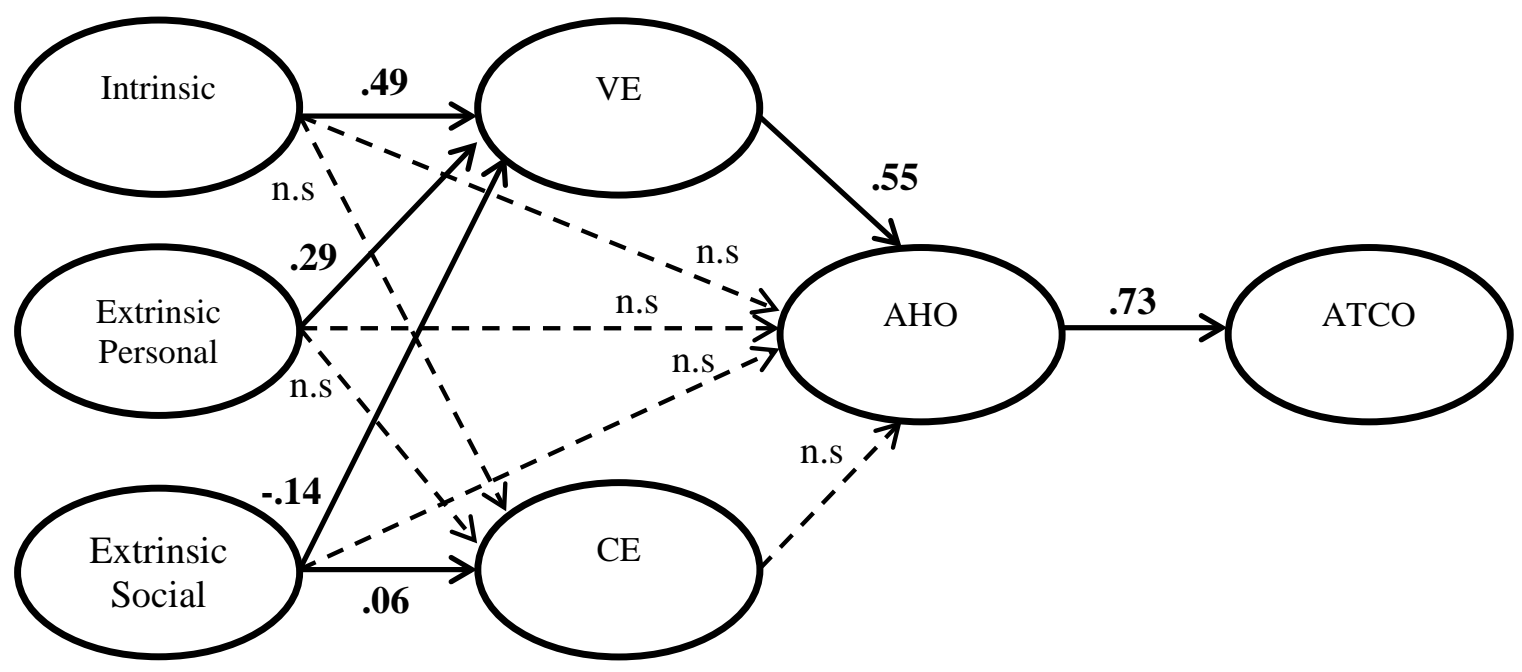

Note: VE = Value Expression; CE = Career; AHO = Attitude Toward Helping Others; ATCO = Attitude Toward Charitable Organization 
Table 1. Demographic Profile

\begin{tabular}{|c|c|}
\hline Demographic & Percentage \\
\hline \multicolumn{2}{|l|}{ Gender } \\
\hline Male & $27.6 \%$ \\
\hline Female & $72.5 \%$ \\
\hline \multicolumn{2}{|l|}{ Marital Status } \\
\hline Single & $95.7 \%$ \\
\hline Married & $1.2 \%$ \\
\hline Others & $3.1 \%$ \\
\hline \multicolumn{2}{|l|}{ Religion } \\
\hline Muslim & $66.3 \%$ \\
\hline Christian & $17.8 \%$ \\
\hline Catholic & $9.7 \%$ \\
\hline Buddhism & $3.1 \%$ \\
\hline Hinduism, & $1.6 \%$ \\
\hline Others & $1.6 \%$ \\
\hline
\end{tabular}


Table 2. Scale items

\begin{tabular}{|c|c|c|}
\hline \multicolumn{2}{|c|}{ Measure } & \multirow{2}{*}{$\begin{array}{l}\text { Source } \\
\text { Allport and Ross, } 1967 \\
\end{array}$} \\
\hline INTRIN & IC RELIGIOSITY (INT) & \\
\hline INT01 & I enjoy reading about my religion. & \\
\hline INT02 & My whole approach to life is based on religion. & \\
\hline INT03 & I try hard to live all my life according to my religious beliefs. & \\
\hline INT04 & It is important to me to spend time in private thought and prayer. & \\
\hline INT05 & I have often had a strong sense of God's presence. & \\
\hline \multicolumn{2}{|c|}{ EXTRINSIC PERSONAL RELIGIOSITY (EXTP) } & Allport and Ross, 1967 \\
\hline EXTP01 & $\begin{array}{l}\text { What religion offers me most is comfort in times of trouble and } \\
\text { sorrow. }\end{array}$ & \\
\hline EXTP02 & Prayer is for peace and happiness. & \\
\hline ЕХТР03 & I pray mainly to gain relief and protection. & \\
\hline \multicolumn{2}{|c|}{ EXTRINSIC SOCIAL RELIGIOSITY (EXTS) } & Allport and Ross, 1967 \\
\hline EXTS04 & I go to religious services mostly to spend time with my friends. & \\
\hline EXTS05 & I go to religious services mostly because it helps me to make friends. & \\
\hline EXTS06 & $\begin{array}{l}\text { I go to religious services mostly because I enjoy seeing people I } \\
\text { know there. }\end{array}$ & \\
\hline \multicolumn{2}{|c|}{ REASON FOR VOLUNTEERING - VALUE EXPRESSION (VE) } & Clary et al., 1998 \\
\hline VE02 & I am genuinely concerned about the particular group I am serving & \\
\hline VE03 & I feel compassion toward people in need & \\
\hline VE04 & I feel it is important to help others & \\
\hline \multicolumn{2}{|c|}{ REASON FOR VOLUNTEERING - CAREER (CE) } & Clary et al., 1998 \\
\hline CE02 & I can make new contacts that might help my business or career & \\
\hline CE03 & Volunteering allows me to explore different career options & \\
\hline CE04 & Volunteering will help me to succeed in my chosen profession & \\
\hline \multicolumn{2}{|c|}{ ATTITUDE TOWARD HELPING OTHERS (AHO) } & Web et al., 2000 \\
\hline AHO01 & People should be willing to help others who are less fortunate. & \\
\hline AHO02 & Helping troubled people with their problems is very important to me. & \\
\hline AHO03 & People should be more charitable toward others in society. & \\
\hline АHO04 & People in need should receive support from others. & \\
\hline \multicolumn{2}{|c|}{ ATTITUDE TOWARD CHARITABLE ORGANIZATION (ATCO) } & Web et al., 2000 \\
\hline ATCO01 & The money given to charities goes for good causes. & \\
\hline ATCO02 & Much of the money donated to charity is wasted. (R) & \\
\hline ATCO03 & My image of charitable organizations is positive. & \\
\hline ATCO04 & $\begin{array}{l}\text { Charitable organizations have been quite successful in helping the } \\
\text { needy }\end{array}$ & \\
\hline ATCO05 & Charity organizations perform a useful function for society. & \\
\hline
\end{tabular}


Table 3. Mean values and Standard Deviations

\begin{tabular}{|l|c|c|}
\hline Construct & Mean & Std. Deviation \\
\hline 1. Intrinsic Religiosity & 4.05 & 0.56 \\
\hline 2. Extrinsic Personal Religiosity & 4.23 & 0.67 \\
\hline 3. Extrinsic Social Religiosity & 2.50 & 0.85 \\
\hline 4. Reason for Volunteering -Value Expression & 4.09 & 0.51 \\
\hline 5. Reason for Volunteering - Career & 3.31 & 0.59 \\
\hline 6. Attitude Toward Helping Others & 3.97 & 0.69 \\
\hline 7. Attitude Toward Charitable Organization & 3.82 & 0.65 \\
\hline
\end{tabular}




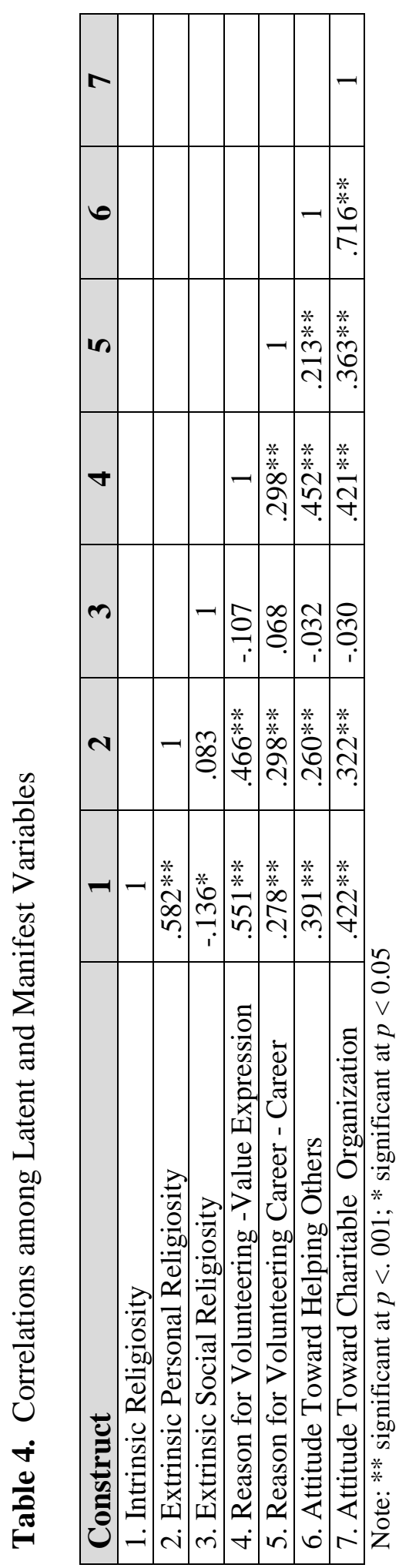


Table 5. Construct Reliabilities and Factor Loadings

\begin{tabular}{lcclc}
\hline CODE & SL & RELIABILITIES & AVE & CR \\
\hline INTRINSIC RELIGIOSITY (INT) & & \\
\hline INT01 & 0.668 & 0.446 & & \\
INT02 & 0.663 & 0.440 & & \\
INT03 & 0.769 & 0.591 & $\mathbf{0 . 8 4}$ \\
INT04 & 0.789 & 0.623 & $\mathbf{0 . 5 1}$ & \\
INT05 & 0.660 & 0.436 & & $\mathbf{0 . 7 9}$ \\
\hline EXTRINSIC PERSONAL (EXTP) & & \\
\hline EXTP01 & 0.664 & 0.441 & $\mathbf{0 . 8 7}$ \\
EXTP02 & 0.702 & 0.493 & & \\
EXTP03 & 0.748 & 0.560 & & \\
\hline EXTRINSIC SOCIAL (EXTS) & & $\mathbf{0 . 6 8}$ & \\
\hline EXTS04 & 0.728 & 0.530 & $\mathbf{0 . 8 6}$ \\
EXTS05 & 0.905 & 0.819 & & \\
EXTS06 & 0.838 & 0.702 & & \\
\hline REASON FOR VOLUNTEERING - VALUE EXPRESSION (VE) & \\
\hline VE02 & 0.738 & 0.545 & & \\
VE03 & 0.607 & 0.368 & $\mathbf{0 . 7 9}$ \\
\hline VE04 & 0.766 & 0.587 & $\mathbf{0 . 5 9}$ & \\
\hline REASON FOR VOLUNTEERING - CAREER (CE) & & \\
\hline CE02 & 0.568 & 0.323 & & \\
CE03 & 0.847 & 0.717 & $\mathbf{0 . 5 7}$ & \\
CE04 & 0.810 & 0.656 & & \\
\hline ATTITUDE TOWARD HELPING OTHERS (AHO) & \\
\hline AHO01 & 0.768 & 0.590 & & \\
AHO02 & 0.841 & 0.707 & & \\
AHO03 & 0.820 & 0.672 & & \\
AHO04 & 0.634 & 0.402 & & \\
\hline ATTITUDE TOWARD CHARITABLE ORGANIZATION (ATCO) & \\
\hline ATCO01 & 0.615 & 0.378 & & \\
ATCO02 & 0.722 & 0.521 & & \\
ATCO03 & 0.791 & 0.626 & & \\
ATCO04 & 0.759 & 0.576 & & \\
ATCO05 & 0.804 & 0.646 & & \\
\hline & & & \\
\hline
\end{tabular}

Note:

1. $\mathrm{SL}=$ Standardized Loading; AVE= Average Variance Extracted; $\mathrm{CR}=$ Composite Reliabilities

2. Fit indices (Measurement Model): CFI = .945; TLI = .937; IFI = .946; RMSEA $=.048 ; \mathrm{X}^{2}{ }_{(283)}=$ 453.914 


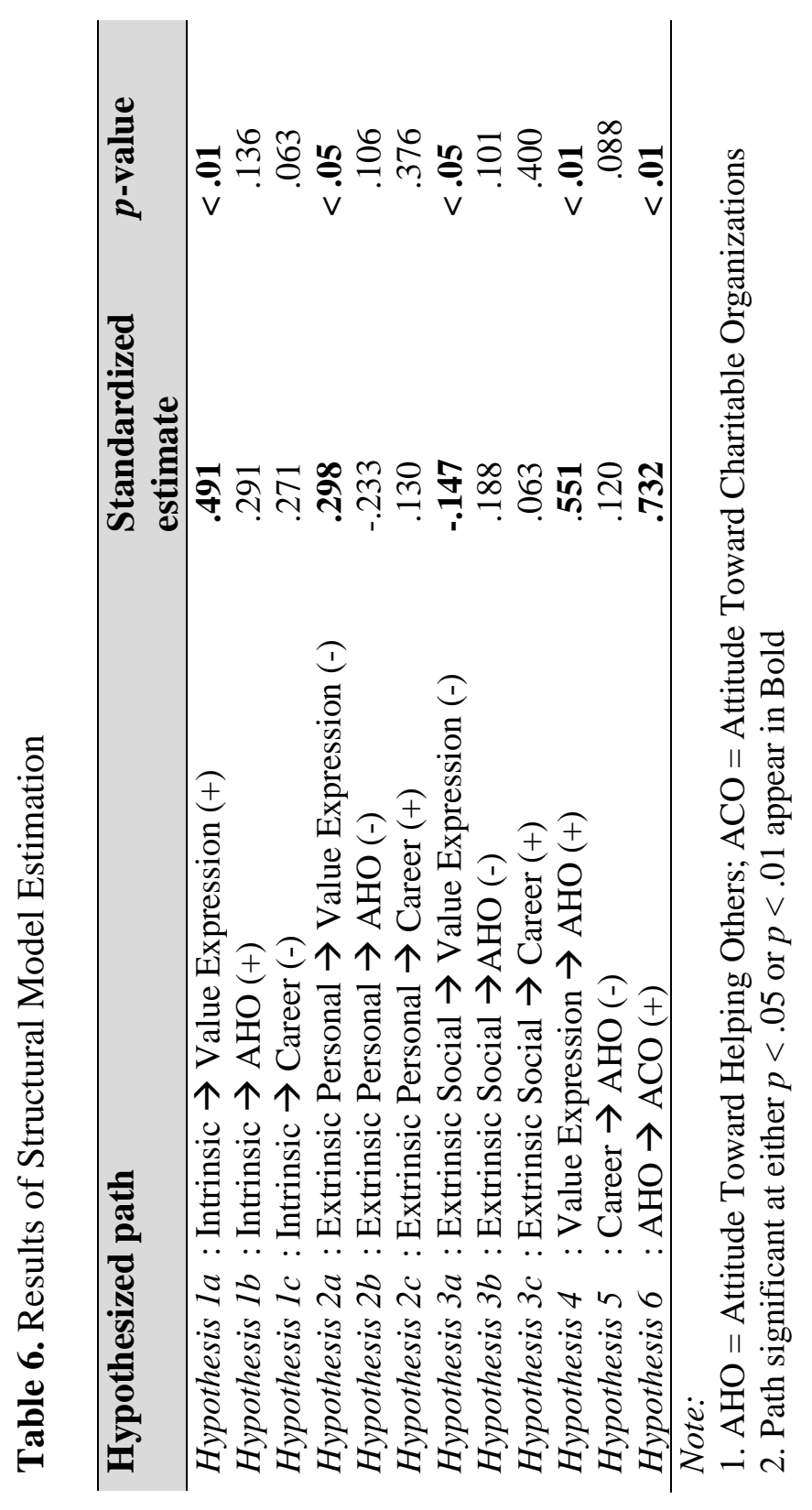

กิ 